\title{
REVISITING THE DUTCH LEXICAL CONTRIBUTION TO MALACCA PORTUGUESE CREOLE
}

\author{
Andrei A. Avram*
}

\begin{abstract}
The paper looks at the Dutch-derived loanwords attested in Malacca Portuguese Creole. The sources cover a period ranging from the last decades of the $19^{\text {th }}$ century to the present day and consist mainly of lexicographical works, but also include folk songs, proverbs and religious texts The loanwords of Dutch origin identified are first listed, with the proposed etyma. This is followed by a discussion of the following topics: other potential etyma and the possibility of multiple etymologies; the proportion of Dutch loanwords in the lexicon of Malacca Portuguese Creole; the phonological adjustment of Dutch loanwords; the syntactic categories to which Dutch loanwords belong; the semantic fields in which Dutch loanwords are found; the semantic changes undergone by some of the Dutch loanwords. Also discussed are some implications of the findings.
\end{abstract}

Keywords: Dutch, loanwords, Malacca Portuguese Creole

\section{Introduction}

Malacca was occupied by the Portuguese in 1511 , but between 1641 and 1795 and between 1818 and 1824 Malacca was under Dutch rule (Holm 1989: 291-292, Hancock 2009: 296).

Malacca Portuguese Creole (henceforth MPC) is spoken by members of the Eurasian community in Malaysia - in Malacca, and, possibly, in Kuala Lumpur - as well as in Singapore (Holm 1989: 291, Pereira 2006: 59, Hancock 2009: 295). MPC is known by many other names. These include, in alphabetical order, the following: Bahasa Geragau', Bahasa Serani ${ }^{2}$, dialecto português de Malaca, Kristang ${ }^{3}$, Luso-Malay, Malacca Creole, Malacca Creole Portuguese, Malaccan, Malaqueiro, Malaquenho, Malaquense, Malaquês, Malayo-Portuguese, Malaysian Creole Portuguese, Papia Cristão or Papia Kristang ${ }^{4}$, Portuguese Patois, Português de Malaca, Serani ${ }^{5}$ (Hancock 1969: 38, Baxter 1988: 1, Morgado da Costa 2020: 37). As shown by Baxter (1988: 1), "the speakers themselves mainly use the term Kristang in their own language".

Estimates of the number of MPC speakers vary: According to Holm (1989: 292), at "the creole-speaking community consists of some 1500 people in Malacca". Hancock (2009: 295) estimates that the number of speakers amounts to "several hundred people,

\footnotetext{
*University of Bucharest, Department of English, andrei.avram@lls.unibuc.ro.

1 'Shrimp language', from Malay bahasa 'language' and geragau 'shrimp'. Baxter (1988: 15) writes that "the Kristangs are well known in Malacca for catching and selling grago, a small shrimp".

2 'Catholic language', from Malay bahasa 'language' and serani 'Christian'.

${ }^{3}$ MPC for 'Christian'.

4 'Christian speech'.

5 'Christian', from Malay serani 'Christian'.

Bucharest Working Papers in Linguistics XXIII, 1, 61-78, e-ISSN 2392-8093, ISSN-L 2069-9239 DOI: 10.31178/BWPL.23.1.3
} 
including children". More recently, in the last update ${ }^{6}$ of the entry Kristang in the online edition of Moseley (2010) the number of speakers is 2150.

Like all Asian Portuguese-lexifier creoles which are still spoken, the prospects for the maintenance of MPC are rather bleak, with the younger generation shifting to Malay and/or English (see e.g. Pinharanda Nunes 1999, Baxter 2005, Lee 2004, Lee 2011, Baxter 2012). In Moseley (2010) the degree of endangerment of MPC is that of "severally endangered", which means that in terms of intergenerational transmission the "language is spoken by grandparents and older generations; while the parent generation may understand it, they do not speak it to children or among themselves". Currently, attempts at revitalizing MPC are made both in Malaysia (Soh 2015, Pillai et al. 2018) and in Singapore (Wong. 2019, Kodrah Kristang n.d.).

As put by Baxter \& de Silva (2004: xvii), "Kristang, like any language which has arisen in a context where several languages were in contact, and which continues to be spoken in this context, naturally uses words originating from other languages". In addition to Portuguese, its lexifier language, MPC has drawn on many other source languages to build its vocabulary. These include Malay, Hokkien, Dutch and English.

The Dutch lexical contribution to MPC has been relatively little studied so far. There are only two works specifically addressing this topic: Hancock (1970) and Avram (2013). In the present paper I take a fresh look at the MPC words of Dutch origin.

The paper is organized as follows. The corpus and methodology are presented in section 2. Section 3 presents the Dutch loanwords attested in MPC. Section 4 discusses the phonological, syntactic and semantic characteristics of the Dutch loanwords. Section 5 summarizes the findings and their implications.

\section{Corpus and methodology}

The main sources for MPC are lexicographical works: da Silva Rêgo vocabulary (1942a), the dictionaries by Baxter \& de Silva (2004) and Scully \& Zuzarte (2017), a glossary (Anon. n.d.) and Pinchah Kristang (Morgado da Costa n.d.), an online dictionary still in the making ${ }^{7}$. Additional data are from: da Silva Rêgo's (1942a, 1942b), consisting of sample sentences, dialogues, proverbs, folk songs, religious texts; Hancock (1970, 1975); Baxter's (1988) grammar; da Silva (1988). As mentioned by Baxter \& de Silva (2004: xii, n. 12), "Kristang is well documented in the twentieth century". However, as shown by Baxter \& de Silva (2004: xii, n. 12), "so far only two documents in Malacca Creole Portuguese have been located from an earlier period, from the nineteenth century". Of these, one dates from 1884 and is a handwritten excerpt from $O$ Novo Testamento escripto no creoulo de Malacca por um missionário portuguez e impresso em Malacca (see Brief (01-264)). The text contains no Dutch-derived lexical items. The other, $A$ mostra de huma conversa familiar (1884?), is "presumably based on native speaker speech" (Baxter 1996: 308). According to Baxter (1996: 308), "the language resembles that of the Malacca Creole Portuguese of texts in Rêgo (1942)" and it is also "close to the

\footnotetext{
${ }^{6}$ February 8, 2017.

${ }^{7}$ For details on this project see Morgado da Costa (2020).
} 
twentieth century language as spoken by elderly Creoles". Baxter (1996: 308) concludes that "it is perhaps the earliest text of Malacca Creole Portuguese of any authenticity". Unfortunately, I did not have access to this text. Under the circumstances, the Dutch loanwords listed are from the $20^{\text {th }}$ - and $21^{\text {st }}$-century sources.

The list of Dutch words in MPC consists of items recorded at any time in the history of the language. Consequently, it includes words which may no longer be in use today or which are currently less frequently used.

The Dutch etyma and their meanings have been established or checked on the basis of the dictionaries by Gerritsen et al. (1978), Bogaards (1988), Van der Sijs (2010) and Woordenboek der Nederlandsche Taal (2012). This has led to the identification of a number of Dutch-derived lexical items for which no etymon is proposed in the sources consulted.

\section{Dutch loanwords in Malacca Portuguese Creole}

\subsection{Format of the list}

The Dutch loanwords in MPC are listed in alphabetical order. By convention, each entry corresponds to the form first attested in chronological order. Each entry consists of the MPC lexical item or phrase, its meaning, the Dutch etymon, and it includes all the variants recorded in the sources mentioned. The meanings indicated in Dalgado (1900) appear in the Portuguese original and those in Anon. (n.d.) both in Portuguese and in English. The glosses are those in the original sources and are reproduced in the original orthography.

In the spelling used in some of the sources $<\breve{\mathrm{a}}>=$ for [ə], $<\mathrm{ci}>=[\mathrm{si}],<\mathrm{ch}>=[\mathrm{t}]$, $<\mathrm{ng}>=[\mathrm{y}]$ and the diacritic ' marks a stressed vowel. Note also that $<\mathrm{e}>$ stands for either [e] or [E], while $<_{0}>$ represents either [o] or [o]. The occurrence of $\langle\mathrm{e}>$ and $<\mathrm{i}>$ and respectively of $<_{0}>$ and $<\mathrm{u}>$ in variants of the MPC lexical items listed below reflects inter-speaker variation ${ }^{8}$.

\subsection{List of Dutch words in Malacca Portuguese Creole}

Listed below are the words of Dutch origin attested in MPC.

ANDÓKU 'towel': andóku 'towel' (Hancock 1970: 353). From Dutch handdoek 'towel'.

APEL 'apple': apel 'apple' (Morgado da Costa n.d.). From Dutch appel 'apple'.

ASKÚNG 'glove': askúng 'glove' (Hancock 1970: 353); ascu 'luvas' (Anon. n.d.); askung 'glove' (Morgado da Costa n.d.). From Dutch handschoen 'glove'.

\footnotetext{
${ }^{8}$ According to Hancock (2009: 298), "for some speakers there is a certain amount of free variation between /i/ and /e/ and /o/ and /u/". For an analysis of the vowels of MPC see Hancock (1973: 25), Baxter (1988: 23-29), and Pillai et al. (2015).
} 
ARTAPEL 'potato': artapel (da Silva Rêgo 1942b: 15): atápăl 'Irish potato' (Hancock 1970: 353); artapal/atapal 'potato' (Baxter \& de Silva 2004: 9); atapel [a:təpel] 'potato' (Scully \& Zuzarte 2017: 49); artápel 'batata' (Anon. n.d.); artapal /atapal/atapel 'potato' (Morgado da Costa n.d.). From Dutch aardappel 'potato'.

BÁSKONG 'wash-basin': báskong 'wash-basin' Hancock (1970: 353); baskung 'wash-basin' Morgado da Costa (n.d.). From Dutch waskom 'wash-basin'.

BERGER 'burgher': berger [bə:gə]'burgher' (Hancock 1970: 353); berger 'burgher' (Morgado da Costa n.d.): berger 'burgher'. From Dutch burger 'citizen'.

BIR 'beer': bir 'beer' (Scully \& Zuzarte 2017: 56); bir 'beer' (Morgado da Costa n.d.). From Dutch bier 'beer'.

BLAU 'blue': blau 'blue' (Hancock 1970: 353); blau 'indigo powder used for whitening clothes' (Baxter \& de Silva 2004: 16); blau 'azul indigo' (Anon. n.d.); blau 'indigo powder used for whitening clothes' (Morgdo da Costa n.d.). From Dutch blauw 'blue'.

BRUDA 'sweets': bruda 'doces' (da Silva Rêgo 1942b: 20); bluda/bruda 'sweet bread-like cake formerly prepared at Christmas' (Baxter \& de Silva 2004: 16); blueda [blu:də] 'a Dutch cake which uses toddy as a raising agent' (Scully \& Zuzarte 2017: 57). From Dutch broeder 'breadcake'.

BOLSA' 'bolster': bolsá 'bolster' (Hancock 1970: 353); bolsak 'mattress' (Baxter \& de Silva 2004: 17); bolsak [bolsa:k] 'mattress' (Scully \& Zuzarte 2017: 58); bolsac 'clochão' (Anon.n.d.); bolsak 'mattress' (Morgado da Costa n.d.). From Dutch bultzak 'straw-mattress'.

BÔTOL 'bottle': bôtol 'garrafa' (da Silva Rêgo 1942b: 47); botěl 'bottle' (Baxter \& de Silva 2004: 18); botel [boutəl] bôtol 'bottle' (Anon. n.d.); botel 'bottle' (Morgado da Costa n.d.). From Dutch bottel '(obsolete) bottle'.

BUIH 'respectful term of address for older brother or brother-in-law': buih 'respectful term of address for older brother or brother-in-law' (Baxter \& de Silva 2004: 19); buih 'respectful term of address for older brother or brother-in-law' (Morgado da Costa n.d.). From Dutch broer 'brother'.

BÚKU 'book': búku 'book' (Hancock 1970: 353); buku 'book' (Baxter 1988: 128); buku 'book' (Baxter \& de Silva 2004: 19); buco 'livro' (Anon. n.d.); buku 'book' (Morgado da Costa n.d.). From Dutch boek 'book'.

BÚNCHIS ‘bean’: búnchis ‘bean’ (Hancock 1970: 353). From Dutch boontjies ‘beans’.

CACUS 'toilet': cacus 'retrete' (da Silva Rêgo 1942a:48); kakús 'latrine' (Hancock 1970: 354); kakus 'toilet' (Baxter \& de Silva 2004: 43); kakus [ka:kus] 'lavatory, toilet' (Scully \& 
Zuzarte 2017: 91); cacus 'retrete; pia' (Anon. n.d.); kakus 'latrine' (Morgado da Costa n.d.). From Dutch kakhuis 'latrine'.

CALBÁS 'gourd': calbás 'garrafão' (da Silva Rêgo 1942b: 15); kalbás 'gourd' (Hancock 1970: 354). From Dutch kalabas/kalebas 'gourd, calabash'.

COFI 'coffee': cofi 'café' (da Silva Rêgo 1942a: 51); kofi 'coffee' (Baxter \& de Silva 2004: 49); kofi [ko:fi] 'coffee' (Scully \& Zuzarte 2017: 97); cofi 'café' (Anon. n.d.); kofi 'coffee' (Morgado da Costa n.d.). From Dutch koffie 'coffee'.

CÓPI 'cup': cópi (da Silva Rêgo 1942b: 12); kópi 'cup' (Hancock 1970: 354); kopi (da Silva 1988: 109); kopi 'cup' (Baxter \& de Silva 2004: 50); korpi [ko:pI] 'cup' (Scully \& Zuzarte 2017: 99); copi 'copo, bacia' (Anon. n.d.); kopi 'cup' (Morgado da Costa n.d.). From Dutch kopje 'cup'.

CRONCHE 'crown': cronche 'coroa; coroa feita de papel de cores ou de flores, simbólica do cabelo amarrado ou atado em cima da cabeça' (da Silva Rêgo 1942b: 11); kronchi 'white and silver mitre-shaped symbol which is hung above doors of the key participants in a Kristang wedding' (Baxter \& de Silva 2004: 52); kronchi [krəuntfI] 'an old Kristang ornament whereby a heart-shaped ornament with a cross on it is displayed on the front door of the houses of the betrothed couple' (Scully \& Zuzarte 2017: 100); kronchi 'white and silver mitre-shaped symbol which is hung above doors of the key participants in a Kristang wedding' (Morgado da Costa n.d.). From Dutch kroontje 'small crown'.

CUQUIS 'sweets': cuquis 'doces' (da Silva Rêgo 1942b: 11); kukís 'cake' (Hancock 1970: 354); kukis 'cake' (Baxter \& de Silva 2004: 53); kukis [ku:kıs] (Scully \& Zuzarte 2017: 102); cuquis 'bolos' (Anon. n.d.); kukis 'cake' (Morgado da Costa n.d.). From Dutch koekjes '(sweet) biscuits, cookies'.

DÁSI 'necktie': dási 'nectie' (Hancock 1970: 353); dasi 'neck-tie' Baxter \& de Silva 2004: 24); dáci 'gravata' (Anon. n.d.); dasi 'necktie' (Morgado da Costa n.d.). From Dutch dasje '(neck-)tie'.

DOI 'dinheiro': doi 'dinheiro' (da Silva Rêgo 1942a: 54); doi 'money' (Hancock 1970: 353); doi 'money' (Baxter 1988: 31); doi 'money' (Baxter \& de Silva 2004: 28); doi [dəui] Scully \& Zuzarte 2017: 70); doi 'denheiro [sic]' (Anon. n.d.); doi 'money' (Morgado da Costa n.d.). From Dutch duit 'farthing'.

DOPA 'fish cooked in batter': dopa 'fish cooked in batter' (Baxter \& de Silva 2004: 28); dopa 'fish cooked in batter' (Morgado da Costa n.d.). From Dutch 'doop- (root of dopen) to dip'.

DUZING 'dozen': duzing 'dozen' (Baxter \& de Silva 2004: 29); duzing 'dozen' (Morgado da Costa n.d.). From Dutch dozijn 'dozen'. 
ELA 'yard (measurement of length)': ela 'yard (measurement of length)' (Baxter \& de Silva 2004: 29); ela 'yard' (Scully \& Zuzarte 2017: 71); ela 'uma yarda (medida)' (Anon. n.d.); ela 'yard' (Morgado da Costa n.d.). From Dutch el '(Dutch) ell'.

ESEN 'perfume': esen 'perfume' (Baxter \& de Silva 2004: 29); esen [æsın] 'essence, perfume' (Scully \& Zuzarte 2017: 71); esen 'perfume; essence; scent; fragance' aroma' (Morgado da Costa n.d.). From Dutch essence 'perfume'.

EUROPEANO 'European': europeano 'europeu' (da Silva Rêgo 1942a: 55); ropiánu 'European' (Hancock 1970: 355); ropianu 'European' (Baxter \& de Silva 2004: 78); ropianu [rəupıa:nu] 'European' (Scully \& Zuzarte 2017: 136); ropianu 'European' (Morgado da Costa n.d.). From Dutch Europeaan 'European'.

FLAU 'faint': flau 'faint' (Scully \& Zuzarte 2017: 75). From Dutch flauw 'faint'.

FLAU 'to faint': flau 'to faint' (Scully \& Zuzarte 2017: 75). From Dutch flauw 'faint'.

FLES 'bottle': fles 'bottle' (Hancock 1970: 354). From Dutch fles 'bottle'.

FLOI 'flute': floi 'flauta' (da Silva Rêgo 1942a: 53); floi 'flute' (Hancock 1970: 354); floi 'flute without keys' (Baxter \& de Silva 2004: 32); floi 'flauta' (Anon. n.d.); floi 'flute' (Morgado da Costa n.d.). From Dutch fluit 'flute'.

FLOI 'to whistle': floi 'to whistle' (Hancock 1970: 354); floi 'flute' (Baxter 1988: 114); floi 'to whistle' (Baxter \& de Silva 2004: 32); floi 'to whistle' (Scully \& Zuzarte 2017: 75); floi 'to whistle' (Morgado da Costa n.d.). From Dutch fluit- '(root of) to whistle'.

FRAI 'pretty, fine': frai 'bonito, gentil' (da Silva Rêgo 1942b: 7); frai 'attractive' (Hancock 1970: 354); frai 'good' Hancock (1975: 224); frai 'cute; precious; cunning' (Morgado da Costa n.d.). From Dutch fraai 'fine, pretty, handsome'.

GLAZ 'glass': glaz 'copo' (da Silva Rêgo 1942b: 27); glas 'drinking glass' (Baxter \& de Silva 2004: 36); glass 'glass; drinking glass' (Morgado da Costa n.d.). From Dutch glas 'glass'.

KALKÚN 'turkey': kalkún 'turkey' (Hancock 1970: 354); Baxter \& de Silva (2004: 44): kalkun 'turkey' Baxter \& de Silva 2004: 44); kalkun [ka:lkun] 'turkey' (Scully \& Zuzarte 2017:91); calcum 'perú' (Anon. n.d.); kalkun 'turkey' (Morgado da Costa n.d.). From Dutch kalkoen 'turkey'.

KANGKA 'cancer': kangka 'cancer' (Baxter \& de Silva 2004: 44); kangka 'cancer' (Morgado da Silva n.d.). From Dutch kanker 'cancer'.

KĂNÓP 'knot': kănóp 'knot' (Hancock 1970: 354); quenop 'knot' (Anon. n.d.). From Dutch knoop 'button; knot'. 
KARPUSA 'baby's bonnet; cap': karpusa 'baby's bonnet; cap' (Baxter \& de Silva 2004: 46); karpusa 'cap; baby's bonnet' (Morgado da Costa n.d.). From Dutch karpoets/karpuits 'fur cap'.

KLOR 'color': klor 'color' (Hancock 1970: 354); klor 'colour' (Baxter 1988: 57); klor 'colour' (Baxter \& de Silva 2004: 49); klor [kləu] 'colour' (Scully \& Zuzarte 2017: 97); clôr 'cor' (Anon. n.d.); klor 'colour' (Morgado da Costa n.d.). From Dutch kleur 'colour'.

KLÓMPU 'clogs': klómpu 'clogs' (Hancock 1970: 354); klompu 'clogs' (Baxter \& de Silva 2004: 49); klompu 'clogs' (Morgado da Costa n.d.). From Dutch klomp 'clogs, wooden shoe'.

KORKI 'cook': korki [ko:kI] 'cook' (Scully \& Zuzarte 2017: 99). From Dutch kok 'cook'.

KROL 'hairstyle': krol 'used only in marah krol to tie up the hair' (Baxter \& de Silva 2004: 52); krall [kra:l] 'hairstyle; a special hairstyle in the old days for Kristang women' (Scully \& Zuzarte 2017: 99). From Dutch krul 'curl'.

KUS 'stockings': kus 'stockings' (Hancock 1970: 354); côs 'meias' (Anon. n.d.). From Dutch kous 'stocking'.

LACHI 'drawer': lachi 'drawer' (Baxter \& de Silva 2004: 54); lachi [la:tfi] 'drawer' (Scully \& Zuzarte 2017: 104); lachi ‘drawer’ (Morgado da Costa n.d.). From Dutch laatje 'small drawer'.

LÁMPU 'lamp': lámpu 'lamp' (Hancock 1970: 354); lampu 'lamp' (Baxter \& de Silva 2004: 55); lampu 'lamp' (Morgado da Costa n.d.). From Dutch lamp'lamp'.

LANFAR 'crepes': lanfar 'crepes' (da Silva Rêgo 1942a: 58); lanfa 'mourning-band of black ribbon worn on left arm' (Baxter \& de Silva 2017: 55); lanfar 'crepes' (Anon. n.d.). From Dutch lamfer 'streamer, crape'.

LAP 'to sponge, to mop': lap 'to sponge, to mop' (Scully \& Zuzarte 2017: 105); lap 'to mop, to sponge' (Morgado da Costa n.d.). From Dutch lap 'piece of cloth, rag'.

LES 'to read': les 'to read' (Hancock 1970: 354); les 'to read' (Baxter 1988: 128); les 'to read' (Baxter \& de Silva 2004: 56); les [lers] 'to read' (Scully \& Zuzarte 2017: 107); les/leis 'to read' (Morgado da Costa n.d.). From Dutch lees- '(root of lezen) to read'.

LÔI 'lazy': lôi 'pessoa preguiçosa' (da Silva Rêgo 1942a: 11); loi 'lazy' (Baxter \& de Silva 2004: 57); loi 'preguiçoso' (Anon. n.d.); loi 'lazy' (Morgado da Costa n.d.). From Dutch lui 'lazy'.

MATROS 'clumsy': matros [ma:trous] 'clumsy' (Scully \& Zuzarte 2017: 112); matros 'clumsy' (Morgado da Costa n.d.). From Dutch matroos 'sailor'. 
$N A$ 'in, to': $n a$ 'in, to' (Hancock 1970: 354); $n a$ 'at; to; on; in' (Baxter \& de Silva 2004: 63); $n a$ [nə] 'at; in; inside; on' (Scully \& Zuzarte 2017: 116); na 'in; to; on; at' (Morgado da Costa n.d.). From Dutch naar 'to'.

NECHIS 'pleasant, pretty, nice': nechis 'agradável, bonito, elegante' (da Silva Rêgo 1942a: 61); niches 'pretty' (Baxter \& de Silva 2004: 64); nechis [netfis]'pretty' (Scully \& Zuzarte 2017: 118); nechis 'agradável, bonito, elegante' (Anon. n.d.); nechis 'pretty' (Morgado da Costa n.d.). From Dutch netjes 'nice'.

$O M$ 'respectful term of address for an old man': om 'respectful term of address for an old man' (Baxter \& de Silva 2004: 67); om 'respectful term of address for an old man' (Morgado da Costa n.d.). From Dutch oom 'uncle'.

ORLÓZI 'clock': orlózi ‘relógio' (da Silva Rêgo 1942a: 63); orlózi ‘clock' (Hancock 1970: 355); olozi [əulozI] 'clock' (Scully \& Zuzarte 2004: 122); orlozi 'relógio' (Anon.n.d.); olozi 'clock' (Morgado da Costa n.d.). From Dutch horloge 'watch'.

PAPAH 'father': papah 'father' (Baxter 1988: 71); papa [pa:pə] 'father' (Scully \& Zuzarte 2017: 123); papa 'father' (Morgado da Costa n.d.). From Dutch papa 'dad'.

PAPOM 'old man': papom 'velho' (da Silva Rêgo 1942a: 41); papong 'term of address for an old man' (Baxter \& de Silva 2004: 86); papom 'velho' (Anon.n.d.); papong 'term of address for an old man' (Morgado da Costa n.d.). From Dutch papa 'father' + oom 'uncle'.

PIKADEL 'shrimp patties': pikadel 'shrimp patties' (Baxter 1988: 60); pikadel 'patty made with shrimp or meat' (Baxter \& de Silva 2004: 72); frikadel [frrkədel] 'patties made from a mixture of mashed potatoes and fish flakes/minced meat' (Scully \& Zuzarte 2017: 77); pikadel [prkədel] 'fish/meat patty' (Scully \& Zuzarte 201: 127); fricadel 'prato de peixe' (Anon. n.d.); frikadel 'small meat or fish patties' (Morgado da Costa n.d.), pikadel 'patty made with shrimp or meat' (Morgado da Costa n.d.). From Dutch frikadel 'minced-meat ball'.

PILAR 'pillar': pilar 'pillar' (Baxter \& de Silva 2004: 73); pilar 'pillar' (Morgado da Costa n.d.). From Dutch pilaar 'pillar, column, post'.

PINCEL 'pencil': pincel [pInsil] 'pencil' (Scully \& Zuzarte 2017: 127); pincel/pinsel 'pencil' (Morgado da Costa n.d.). From Dutch penseel 'pencil'.

PLOI 'wrinkle; fold': ploi 'wrinkle; fold' (Baxter \& de Silva 2004: 73); ploi 'fold; wrinkle' (Morgado da Costa n.d.). From Dutch plooi 'fold; pleat; wrinkle'.

PÓCHI 'pot': póchi 'pot' (Hancock 1970: 355); pochi 'teapot' (Baxter \& de Silva 2004: 73); pochi [poutfi:] 'teapot' pochi/poci 'teapot' (Morgado da Costa n.d.). From Dutch potje 'small pot'. 
PÓCHI-TÉ 'teapot': póchi-té 'teapot' (Hancock 1970: 355); pochiteh 'teapot' (Baxter \& de Silva 2004: 73); pochiteh 'teapot' (Morgado da Costa n.d.). From Dutch potje '(small) pot' + thee 'tea'.

POLBA 'gunpowder': polba 'gunpowder' (Baxter \& de Silva 2004: 73); polba 'gunpowder' (Morgado da Costa n.d.). From Dutch pulver '(gun)powder'.

QUELDER 'funerary monument': quelder 'monumento fúnebre' (da Silva Rêgo 1942a: 36); kelda 'tombstone' (Baxter \& de Silva 2004: 47); quelder 'campa, monumento funebre [sic]' (Anon. n.d.); kelda 'tombstone' (Morgado da Costa n.d.). From Dutch kelder 'cellar'.

RÉTU 'right': rétu 'right, correct' (Hancock 1970: 355); retu 'correct' (Baxter 1988: 26); retu 'correct, right; true' (Baxter \& de Silva 2004: 77); retu [rætu] 'correct, right' (Sculy \& Zuzarte 2017: 135); retu 'truthful; true' (Morgado da Costa n.d.). From Dutch recht 'straight; right; correct'.

SAKU 'pocket': saku 'pocket' (Baxter \& de Silva 2004: 79); saku [sa:ku] 'pocket' (Scully \& Zuzarte 2017: 137); saku 'pocket' (Morgado da Costa n.d.). From Dutch zak 'pocket'.

SALDREH 'celery': saldreh 'celery' (Morgado da Costa n.d.). From Dutch selderij 'celery'.

STAL 'stable': stal 'stable' (Baxter \& de Silva 2004: 84); stal 'stable' (Morgado da Costa n.d.). From Dutch stal 'stable'.

STRIKI 'iron (for ironing clothes)': striki 'iron (for ironing clothes)' (Baxter \& de Silva 2004: 84); striki 'iron (clothes)' [striki:] (Scully \& Zuzarte 2017: 145); striki 'iron' (Morgado da Costa n.d.). From Dutch strijker 'iron'.

STRIKI 'to iron': striki 'passar a ferro' (da Silva Rêgo 1942a: 69); striká 'to iron (clothes)' (Hancock 1970: 355); strikah 'to iron' (Baxter \& de Silva 2004: 84); strikah [strika:] 'to iron (clothes)' (Scully \& Zuzarte 2004: 145); striqui 'passar a ferro' (Anon. n.d.); strike 'to iron out' (Morgado da Costa n.d.). From Dutch strijk- '(root of strijken) to iron'.

STROI 'confetti': stroi 'confetti' (Baxter \& de Silva 2004: 84); stroi 'confetti' (Morgado da Costa n.d.). From Dutch strooi- '(root of strooien) 'to strew; to scatter; to sprinkle'.

SÚCI 'eldest sister': súci 'irmã mais velha' (da Silva Rêgo 1942a: 41), suçi 'irmã' (da Silva Rêgo 1942a: 69); susi 'elder sister' (Baxter 1988: 95); susi 'eldest sister' (Baxter \& de Silva 2004: 85); susi [su:sI] 'sister' (Scully \& Zuzarte 2017: 146); susi 'eldest sister' (Morgado da Costa n.d.). From Dutch zus/zusje '(familiar) sister, sis'.

SUCRE 'sugar': sucre 'açucar' (da Silva Rêgo 1942a: 69); súkri 'sugar' (Hancock 1970: 355); sukri 'sugar' (Hancock 1975: 219); sukri 'sugar' Baxter \& de Silva 2004: 85); sukri 'sugar' (Scully \& Zuzarte 2017: 146); sucre 'sugar' (Anon. n.d.); sukri 'sugar' (Morgdo da Costa n.d.). From Dutch suiker 'sugar'. 
TAFLÁ(K) 'table cloth': taflá(k) 'table cloth' (Hancock 1970: 355); taflak 'tablecloth' (Baxter \& de Silva 2004: 86); taflac 'toalha de mesa' (Anon. n.d.); taflak 'tablecloth' (Morgado da Costa n.d.). From Dutch tafellaken 'table cloth'.

TANTA 'aunt': tanta 'tia' (da Silva Rêgo 1942a: 41); tánta 'aunt' (Hancock 1970: 355); tanta 'aunt, respectful term of address for older woman' (Baxter \& de Silva 2004: 86); tanta [ta:ntə] 'aunt' Scully \& Zuzarte 2017: 147); tanta 'tia' (Anon. n.d.); tanta 'aunt' Morgado da Costa n.d.). From Dutch tante 'aunt'.

TAT 'tart': tat 'pineapple jam tart' (Morgado da Costa n.d.). From Dutch taart 'cake'.

TATOM 'uncle': tatom 'tio' (da Silva Rêgo 1942a: 41); tatom 'uncle' (Baxter \& de Silva 2004: 86); tatom 'tio' (Anon. n.d.); tatom 'uncle' (Morgado da Costa n.d.). From tata 'father' + Dutch oom 'uncle'.

TEH 'tea': in the compound pochiteh 'teapot'. From Dutch thee 'tea'.

ÚMPI 'uncle': úmpi 'uncle' (Hancock 1970: 355). From Dutch oompje 'diminutive of oom 'uncle'.

\section{Discussion}

\subsection{Etyma}

A number of Dutch loanwords illustrate reanalysis of morphemic boundaries. Two of these contain the Dutch plural marker $-s$ : búnchis 'bean' < boontje $+-s$; cuquis/kukis 'cake' < koekje $+-s$. Five loanwords contain allomorphs of the Dutch diminutive suffix: copi/kopi/korpi 'cup' < kop + -je; dasje '(neck)tie' < das + -je; cronche/kronchi 'white and silver mitre-shaped symbol which is hung above doors of the key participants in a Kristang wedding' < kroon +-tje; pochilpóchi 'teapot' < pot + -je; úmpi 'uncle' $<$ oom +-pje.

In some MPC forms stress placement points to a Dutch etymon, rather than an English one. One such case is that of duzing 'dozen', which is transcribed duzing by Baxter \& de Silva (2004: 29). In their system of transcription, "the stressed syllable is underlined in the main entry for each word" (Baxter \& de Silva 2004: xii). The final syllable of the MPC form carries stress, as in its Dutch counterpart dozijn [do'zeIn]. Consider also europeano/ropiano/ropianu/ropiánu 'European', in which the syllable [a] carries stress. As put by Hancock (1970: 355), "the stress-bearing syllable [...] suggests a Dutch, rather than an English derivation": in Dutch europeaan [ørope.a:n] it is the syllable containing the vowel [a:] that is stressed. The same holds for pilar 'pillar'. Baxter \& de Silva (2004: 73) transcribe its as pilar, where the underlined syllable is the stress-carrying one. Here again stress falls on the same syllable as in the Dutch etymon pilaar [pi'la:r].

In the remaining part of this section I discuss the etyma suggested for a number of selected MPC words. 
MPC apel 'apple' appears to be of Dutch origin. The adoption of the Dutch loanwords may have been facilitated by the fact that the masang, from Portuguese maça 'apple', has undergone semantic shift and means 'plum' in MPC.

According to van der Sijs (2010: 216), Malay bir 'beer' is of Dutch origin. This strengthens the case for a Dutch etymon for MPC bir 'beer' as well.

Baxter \& de Silva (2004: 16) propose Dutch brood 'bread' as the etymon of bludal bruda 'sweet bread-like cake formerly prepared at Christmas'. Similarly, in the entry brood 'baksel uit gerezen deeg', van der Sijs (2010: 244) includes "CREOOLS-PORTUGEES (MALAKKA) bluda, bruda 'cake traditioneel gemaakt op Kerstmis'. However, a more likely etymon is, as indicated in section 3, Dutch broeder 'breadcake'. A phonetically similar form, burdar, is attested in Sri Lanka Portuguese Creole (Avram 2013: 54), which van der Sijs (2010: 242) rather inconsistently derives etymologically from Dutch broeder 'koek van meeel, krenten, rozijnen en sukade'.

Circumstantial evidence that buih 'respectful term of address for older brother or brother-in-law' is derived etymologically from Dutch is provided by the fact that a phonetically similar form with a similar meaning, bú/búa 'elder brother', is attested in Sri Lanka Portuguese Creole (Avram 2013: 54).

As already shown by Hancock (1970: 353), búku 'book', this is "historically probably Du rather than Eng-derived". . A Dutch etymon is also indicated by Baxter \& de Silva (2004: 19).

Cofi/kofi 'coffee' is very probably of Dutch origin, given that is rather unlikely that the word only entered MPC after the first contacts with English.

Duit 'farthing', the etymon of MPC doi 'money', is obsolete in Dutch, in which it is mainly used in idiomatic expressions.

I concur with van der Sijs (2010: 322) in tracing glaz/glas 'glass' to Dutch glas. A Dutch etymon is more likely than English glass, suggested by da Silva Rêgo (1942b: 27) or multiple etymology, i.e. Dutch glas and English glass, as proposed by Baxter \& de Silva (2004: 36). Note that Malay gelas 'glass' is of Dutch origin as well (van der Sijs 2010: 322).

With respect to MPC klor 'colour', Hancock (1970: 354) writes "cf. archaic Ptg color". The earlier Portuguese form might account for the MPC form listed by da Silva Rêgo (1942a: 51): color ${ }^{10}$ 'côr'. However, da Silva Rêgo's (1942a: 51) tentative explanation that "a epêntese das duas letras talvez se explique com a influência da palavra inglêsa colour" cannot be accepted.

Regarding MPC lámpu 'lamp', for which he suggests Dutch lamp as its etymon, Hancock (1970: 354) adds "possibly Eng lamp". However, should English lamp be the etymon the MPC form would be expected exhibit [e] or [æ] as a reflex of English [æ]. Also, English loanwords do not exhibit a paragogic vowel. Hence, a Dutch etymon is more likely on phonetic grounds.

MPC na 'in, to' may be traced back not only to Dutch naar, but also to Portuguese $n a$, in confirmation of Hancock's (1970: 354-355) conclusion that "the likelihood of [...] Ptg-Du convergence should not however be discounted".

\footnotetext{
${ }^{9} \mathrm{Du}=$ Dutch, and Eng $=$ English.

${ }^{10} \mathrm{Ptg}=$ Portuguese.
} 
For olozi/orlózi/orlozi 'clock', a Dutch etymon is more likely than the archaic Portuguese form horloge, mentioned by Hancock (1970: 355), but not by any other authors. While there is an archaic Portuguese form horológio 'clock', this is a rather unlikely etymon, given that Portuguese word-final $/ \mathrm{u} /$ is generally preserved in MPC.

Póchi-télpochiteh 'tea pot', literally 'small pot + tea' reflects the constituent order typical of Malay, i.e. the original Dutch theepotje 'tea pot' underwent realignment to the Malay pattern.

On phonetic grounds, polba 'gunpowder' is very probably of Dutch origin, rather than Portuguese-derived. The MPC form is disyllabic and so is its suggested Dutch etymon pulver. Also, as shown in 4.5, in Dutch-derived lexical items $/ \mathrm{r} /$ is deleted. Positing a Portuguese etymon, pólvora 'gunpowder', would further presuppose the syncope of the second syllable and the loss of intervocalic $/ \mathrm{r} /$.

Hancock (1970: 355) writes that rétu 'right' may derive etymologically from Dutch recht and also from Portuguese correcto, via aphaeresis, i.e. [koretu] $>$ [retu]. However, the possibility of convergence with Portuguese-derived dretu should not be ruled out ${ }^{11}$.

According to Hancock (1970: 355), striká is "probably Ptg-derived, [its] use having been reinforced by the very similar Du form". However, the MPC word is more plausibly derived from the Dutch etymon suggested in section 3.

The Dutch-derived form télthe 'tea' must have existed in earlier stages of MPC, along with cha, from Portuguese chá 'tea'. Evidence in this respect is provided by póchi-télpochiteh 'teapot', in which it still survives. Moreover, the realignment of the Dutch compound theepotje 'teapot' to the Malay pattern is further proof that at some point in time télthe was part of the lexicon of MPC, functioning as a synonym of Portuguese-derived cha.

\subsection{Number and proportion of Dutch loanwords}

The number of Dutch loanwords in MPC, listed in section 3, amounts to 79. It is instructive to compare the current findings with those reported by other researchers. According to Hancock (1970: 352), "an examination of the vocabulary of Papia Kristang [...] indicates the presence of some thirty five items traceable, or possibly traceable, to Dutch". Hancock (1970: 352) further states that these Dutch-derived items "constitute less than $2 \%$ of the available lexicon of ca. 2,000 words". In a later paper, Hancock (2009: 5) writes that "the Dutch contribution to the lexicon amounts to about 30 words". Baxter and de Silva (2004) trace 41 words to a Dutch etymon. Scully \& Zuzarte (2017), who mention rather inconsistently the etyma of the non-Portuguese derived lexicon of MPC, trace none of the words listed to a Dutch etymon. Finally, in the glossary of MPC by Anon. (n.d.) 18 are marked as "hol. [= holandês]".

In light of the list in section 3, the number and proportion of Dutch loanwords in MPC recorded in the five lexicographical sources consulted is set out in Table 1 below:

\footnotetext{
${ }^{11}$ A similar case of free variation is rentu $\sim$ drentu 'inside' (Baxter \& de Silva 2004: 77).
} 
Table 1. Number and proportion of Dutch loanwords in MPC

\begin{tabular}{lccc}
\hline Source & $\begin{array}{c}\text { Number of } \\
\text { entries }\end{array}$ & $\begin{array}{c}\text { Number of } \\
\text { Dutch loanwords }\end{array}$ & $\begin{array}{c}\text { Percentage of } \\
\text { Dutch loanwords }\end{array}$ \\
\hline Da Silva Rêgo (1942a) & 835 & 16 & 1.91 \\
Hancock (1970) & 2000 & 36 & 1.80 \\
Baxter \& de Silva (2004) & 2429 & 54 & 2.22 \\
Scully \& Zuzarte (2017) & 2503 & 38 & 1.51 \\
Anon. (n.d.) & 1523 & 32 & 2.10 \\
\hline
\end{tabular}

A few remarks are in order here. In addition to the 16 Dutch loanwords listed in the "Vocabulário" (da Silva Rêgo 1942a: 42-71), 6 more words occur in the texts published by da Silva Rêgo (1942a: 3-42, 1942b). The highest number of Dutch loanwords is found in Baxter \& de Silva's (2004) dictionary; this includes, however, 16 words which the authors do not trace to a Dutch etymon. Similarly, the glossary of MPC by Anon. (n.d.) contains 14 more Dutch-derived items. Note that number of Dutch loanwords in all these sources is well below the total of 79 words presented in section 3 .

\subsection{Semantic fields}

Hancock (1970: 355) rightly concludes with respect to MPC that "the greatest sphere of Dutch influence [...] was undoubtedly in the home". This is indeed the case of MPC forms such as: ándoku 'towel'; báskong/baskung 'wash-basin'; bolsálbolsa/bolsak 'bolster, mattress'; botel/bôtol 'bottle'; cacus/kakus 'latrine, toilet'; copi/kopi/kopi 'cup'; fles 'bottle'; glaz/glaz 'glass'; korki 'cook'; lachi 'drawer'; lampu/lámpu 'lamp'; olozi/orlózi/orlozi 'clock'; pochi/póchi 'teapot'; pochiteh/póchi-té 'teapot'; stal 'stable'; striki 'iron (for ironing clothes); taflac 'tablecloth'.

Another relatively well represented semantic field is that of food. Relevant MPC forms are: artapal/artápel atapal/atápăl/atapel 'potato'; bluda/bruda 'sweet bread-like cake formerly prepared at Christmas'; búnchis 'bean'; calbás/kalbás 'gourd'; cofi/kofi 'coffeee'; cuquis/kukis 'cake'; dopa 'fish cooked in batter'; pikadel 'shrimp patties', frikadel 'patties made from a mixture of mashed potatoes and fish flakes/minced meat'; saldreh 'celery'; sucre/sukri/súkri 'sugar'; tar/tat 'tart'; télteh 'tea'.

Consider also the semantic field of lexical items referring to clothing, illustrated by the following Dutch-derived MPC forms: asculáskung/asking 'gloves'; côs/kus 'stockings'; dáci/dasi/dási 'neck-tie'; karpusa 'baby's bonnet; cap'; klompu/klómpu 'clogs'; ploi 'wrinkle; fold'; saku 'pocket'.

Last, but not least, there are also three terms designating degrees of kinship: papah 'father'; suçi/susi/súsi 'elder/eldest sister'; tanta 'aunt' .

\subsection{Syntactic categories}

Unsurprisingly, the overwhelming majority of the MPC lexical items of Dutch origin are nouns. As shown in section 3, two of these are etymologically derived from 
other syntactic categories. A first such case is that of blau 'indigo powder used for whitening clothes', derived from a Dutch adjective. A second one is dopa 'fish cooked in batter', derived from a Dutch verb.

Three MPC adjectives are of Dutch origin: blau 'blue'; frai 'attractive; good; cute, precious, cunning'; lôi/loi 'lazy'.

Finally, there are four Dutch-derived verbs: flau 'to faint'; floi 'to whistle; lap 'to sponge, to mop'; les/leis 'to read'. Note, however, that, as shown in section 3, lap 'to sponge, to mop' is etymologically derived from a Dutch noun.

\subsection{Phonological adjustment}

The Dutch-derived lexical items undergo various types of phonological adjustment, both at the level of both individual sounds and syllable structure.

There are two MPC reflexes of Dutch /œ/: [ə], as in berger [bəgə] 'burgher' < burger

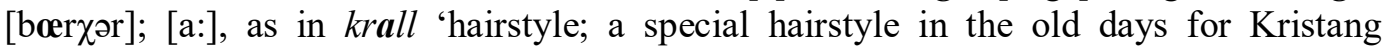
women' < krul [krœl]; [o], as in polba 'gunpowder' < pulver [pœlvər].

The Dutch diphthong /EI/ is rendered by: [e], in saldreh 'celery' < selderij [seldəreI]; [i], in duzing 'dozen' < dozijn [dozeIn].

The Dutch diphthong /œy/ has two MPC reflexes. One is [u], as in kakus 'latrine' < kakhuis [kakœys], sucre/sukri/súkri 'sugar'< suiker [sœykər]. The second one is the diphthong [oi], as in doi 'money' < duit [doyt], floi 'flute' < fluit [flœyt], loi 'lazy' < lui [loy].

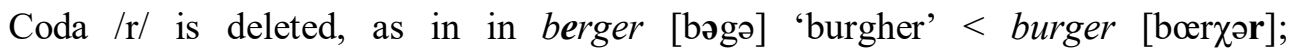
bluda/bruda 'sweet bread-like cake formerly prepared at Christmas' < broeder [bru:dər]; lanfa 'mourning-band of black ribbon worn on left arm' < lamfer [lamfər]; tat 'pineapple jam tart' < tart [ta:rt].

MPC [ $\mathrm{y}$ ] corresponds in coda position to Dutch $/ \mathrm{m} /$, in e.g. báskong/baskung 'wash-basin' < waskom [waskom], and to Dutch /n/, in ascu/askung/askúng 'glove' < handschoen [hantstu:n].

Dutch $/ \chi /$ has two reflexes: [k], in ascu/askung/askúng 'glove' < handschoen

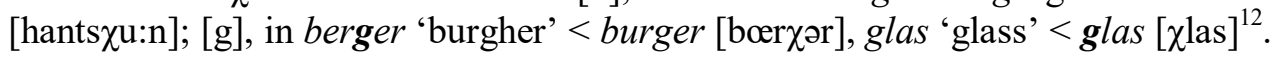

Dutch /h/ is deleted: andóku 'towel' < handdoek 'towel'; ascu/asking/askúng 'gloves' < handschoen [hantsұu:n]; cacus/kakus/kakús 'latrine, toilet' < kakhuis [kakhœys]. Note that word-initial $/ \mathrm{h} /$ is frequently deleted in Malay.

Consider, finally, the repair strategies employed at the level of syllable structure. Some etymological onset clusters are either simplified, as in pikadel 'shrimp patties' < frikadel [frikadel], or broken up by an epenthetic vowel: kănop/quenop 'knot' $<$ knoop [kno:p].

Word-medial consonant clusters undergo reduction, e.g. ascu/askung/askúng

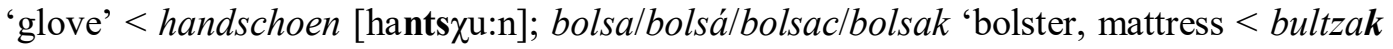
[bœltzak].

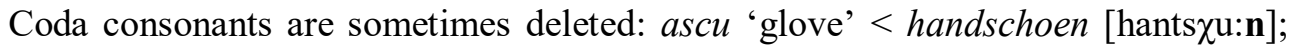
bolsá 'bolster, mattress' < bultzak [bœltzak]; doeh 'nappy' < doek [duk]; floi 'whistle' <

\footnotetext{
${ }^{12}$ Cf. the Malay forms burger (Ling et al. 2007: 628) and gelas (Ling et al. 2007: 691).
} 
fluit [flœyt]. Deletion of word-final $/ \mathrm{k} /$ may reflect the influence of Malay, in which it is realized as the glottal stop [?].

Several forms exhibit paragogic vowels. These include andóku 'towel', buco/ buku/búku 'book' < boek; ela 'yard (measurement of length)' < el; karpusa 'baby's bonnet; cap' < karpoets/karpuits; klompu 'clogs' < klomp; korki 'cook' < kok; lampu 'lamp'<lamp ${ }^{13}$.

\subsection{Semantic changes}

Most MPC words of Dutch origin preserve the meanings of their etyma. However, as shon below, semantic shift occurs in a number of MPC forms.

For instance, blau 'indigo powder used for whitening clothes' illustrates metonymical change from the meaning 'blue' of the Dutch etymon.

A first example of specialization/narrowing of meaning is cronche/kronchi 'white and silver mitre-shaped symbol which is hung above doors of the key participants in a Kristang wedding', derived from an etymon which simply means 'small crown'.

A radical semantic shift, and less easy to explain, is illustrated by Dutch kelder 'cellar' which has yielded MPC quelder/kelda with the meaning of 'tombstone'.

Another example of specialization/narrowing of meaning is that of $\mathrm{krol} / \mathrm{krall}$, where the meaning 'curl' of the Dutch etymon has developed into 'hairstyle; a special hairstyle in the old days for Kristang women'.

The case of lap 'to sponge, to mop' is another example of metonymical change from the meaning 'piece of cloth, rag' of its Dutch etymon.

The meaning 'clumsy' of MPC matros, can probably be traced to the waddling gait typical of sailors having spent a long period of time at sea. Evidence in support of this claim is also provided by the MPC idiomatic expression andah kemah matros 'to walk in a clumsy manner' (Scully \& Zuzarte 2017: 112).

Yet another instance of specialization/narrowing of meaning is póchi/pochi 'teapot', given that its etymon simply means 'small pot', i.e. regardless of what it is used for.

Finally, sacco/saco 'pocket' illustrates semantic extension. The MPC words is derived etymogically from Portuguese, but it has extended its original meaning of 'bag' with that of 'pocket', under the influence of Dutch zak 'pocket'.

\section{Conclusions}

As shown in section 1, MPC is a severely endangered language. Therefore, this paper is also a contribution to a better documentation of the sources upon which MPC has drawn to build its lexicon.

The list in section 3 of words of Dutch origin found in MPC is the most comprehensive one to date. The number of Dutch loanwords in MPC, amounting to 79, is considerably higher than in any other previous works, including Avram (2013) in which only 50 such items are listed.

\footnotetext{
${ }^{13}$ Cf. Malay lampu (Ling et al. 2007: 821).
} 
An assessment of the extent of the Dutch lexical influence on MPC is hindered by two factors. A first one is the paucity of earlier, i.e. pre- $20^{\text {th }}$-century sources, mentioned in section 2. A second one resides in the fact that, as noted by Hancock (1970: 356) "the frequency of Dutch-derived words seems to be declining". The list of MPC lexical items of Dutch origin in section 3 includes several archaisms and words which are no longer in use: doeh 'nappy', teh 'tea', and the following terms of address: om 'respectful term of address for an old man', papom/papong 'term of address for an old man', and tanta 'respectful term of address' tatom 'uncle' ${ }^{14}$. Moreover, Hancock (2009: 299) notes that "Malay words are constantly being adopted into the language" and that "the use of English-derived words in Papia Kristang is increasing". Loanwords of English origin compete with or are in the process of ousting some Dutch-derived items. The following are cases in point. Dutch-derived apel 'apple' competes with English-derived epal (Morgado da Costa n.d.). With respect to blau 'blue' Hancock (1970: 353) notes that "the Eng form blu is more common in $\mathrm{PK}^{15}$ ". Similarly, kangka 'cancer' is used in parallel with with Englih-derived kansar (Morgado da Costa n.d.). Tanta 'aunt', once competing only with Portuguese-derived tia, is facing competition from the English loanword enti (Baxter \& de Silva 2004: 29, Scully \& Zuzarte 2017: 71, Morgado da Costa n.d.).

Dutch is, after Portuguese and Malay, the third most important source of the lexicon of MPC. Therefore, Baxter (1988: 224) was certainly right when writing that "the processes whereby Dutch words have been adopted into Kristang deserve attention". A plausible answer is the gradual integration of Dutch families into the MPC-speaking community. According to Baxter (1988: 6), "very few Dutch women emigrated to the East" and that this as well as "the rigid religious, caste and social systems of the colonsied countries restricted the Dutchmen to women of Eurasian, low class or slave origins". A similar point is made by De Witt (2011: 267), who writes that "in Malacca [...] a large number of Dutchmen who were stationed in the colony married women from the local Portuguese Eurasian community". Baxter (1988: 6) notes that "the extent to which the Dutch and Dutch Eurasians in Malacca may have used Creole Portuguese is unclear", but rightly states that "it is highly likely that it would have been used by their mestiço and indigenous wives and their children" and "even more likely [...] by their slaves". Consequently, as put by De Witt (2011: 267), "many children of Dutch fathers had a better command of [Kristang] learnt from their mothers rather than having fluency in Dutch". According to De Witt (2011: 267), "by the eighteenth century, the Malacca Portuguese Eurasian culture had become well rooted in the Malacca Dutch community". Presumably, then, it is during this process that Dutch words found their way into MPC.

Finally, 21 of the 79 MPC words (and their variants) identified are not listed in the comprehensive "Alfabetisch lexicon van Nederlandse uitleenwoorden" in Van der Sijs (2010: 163-723). Therefore, this paper also illustrates the wider than hitherto assumed distribution of Dutch loanwords in the world's languages.

\footnotetext{
${ }^{14}$ The use of om, papom/papong and tanta as terms of address appears to have been modelled on the Malay equivalents pak cik 'uncle' and mak cik, respectively.

${ }^{15} \mathrm{PK}=$ Papia Kristang.
} 


\section{References}

Anon. n.d. Gloçário de português de Malaca. http://rcl.com.sapo.pt/Malaca Dicionario.html.

Avram, A. A. 2013. The Dutch lexical contribution to three Asian Portuguese creoles. Papia: Revista Brasileira de Estudos Crioulos e Similares 23 (1): 51-74.

Baxter, Allan N. 1988. A Grammar of Kristang (Malacca Creole Portuguese). Canberra: The Australian National University.

Baxter, A. N. 1996. Portuguese in the Pacific and Pacific Rim. In S. A. Wurm \& P. Mühlhäusler (eds.), Language Atlas for Intercultural Communication in the Pacific Rim Area, 299-338. Berlin: Mouton de Gruyter.

Baxter, A. N. 2005. Kristang (Malacca Creole Portuguese) - a seriously endangered language. Estudios de Sociolingüistica 6 (1): 1-37.

Baxter, A. N. 2012. The Creole Portuguese language of Malaca: A delicate ecology. In L. Jarnagin (ed.), Culture and Identity in the Luso-Asian World: Tenacities and Plasticities, 115-142. Singapore: Institue of Southeast Asian Studies.

Baxter, Allan N. \& Patrick de Silva. 2004. A Dictionary of Kristang (Malacca Creole Portuguese) - English. Canberra: The Australian National University.

Bogaards, P. 1988. Dictionnaire français-néerlandais et néerlandais-français. Paris: Dictionnaire Le Robert; Utrecht / Antwerp: Van Dale Lexicographie.

Brief (01-2614) von José dos Santos Vaquinhas an Hugo Schuchardt, 3 November 1884. http://schuchardt. uni-graz.at/id/letter/4102.

Gerritsen, J., N. E. Osselton \& R. W. Zandvoort. 1978. Nederlands-Engels Woordenboek. Groningen: Wolters-Noordhoff.

Hancock, I. F. 1969. The Malacca creoles and their language. Afrasian III: 38-45.

Hancock, I. F. 1970. Some Dutch-derived items in Papia Kristang. Bijdragen tot de Taal-, Land-en Volkenkunde 126(3): 352-356.

Hancock, I. F. 1973. Malacca Creole Portuguese: A brief transformational account. Te Reo 16: 23-44.

Hancock, I. F. 1975. Malacca Creole Portuguese: Asian, African or European? Anthropological Linguistics 17 (5): 211-236.

Hancock, I. F. 2009. The Portuguese creoles of Malacca. Revue roumaine de linguistique LIV (3-4): 295-306.

Holm, J. 1989. Pidgins and Creoles, vol. II, Reference Survey. Cambridge: Cambridge University Press.

Kodrah Kristang. n.d. The initiative for the revitalization of the Kristang language in Singapore. https://kodrah.kristang.com.

Lee, E. 2004. Language Shift and Revitalization in the Kristang Community, Portuguese Settlement, Malacca. PhD dissertation, University of Sheffield.

Lee, E. 2011. Language maintenance and competing priorities at the Portuguese Settlement, Malacca. Ritsumeikan Journal of Asia Pacific Studies 30: 77-99.

Ling, T., Musa, A. \& Seaton, M. (eds.). 2007. Collins Easy Learning English-Malay Bahasa Malaysia-Inggeris Dictionary. Glasgow: HarpersCollins Publishers.

Morgado da Costa, L. 2020. Pinchah Kristang: A dictionary of Kristang. In I. Kernerman, S. Krek, J. P. McCrae, J. Gracia, S. Ahmadi \& B. Kabashi (eds.), Proceedings of the LREC 2020 Globalex Workshop on Linked Lexicography, 37-44. Paris: European Language Resources Association (ELRA).

Morgado da Costa, L. n.d. Pinchah Kristang. http://dictionary.kristang.com.

Moseley, C. (ed.). 2010. Atlas of the World's Languages in Danger, $3^{\text {rd }}$ edition. Paris: UNESCO Publishing. Online version: htts:www.unesco.org/languages-atlas.

Pereira, Dolce. 2007. Crioulos de base portuguesa. Lisbon: Caminho.

Pillai, S., Chan, M. E. \& Baxter, A. N. 2015. Vowels in Malacca Portuguese Creole. Research in Language 13 (3): 248-265.

Pillai, S., Philip, A. \& Soh, W.-Y. 2018. Revitalizing Malacca Portuguese Creole. In P.Trifonas \& T. Aravossitas (eds.), Handbook of Research and Practice in Heritage Language Education, 801-817. Cham: Springer.

Pinharanda Nunes, M. 1999. The use of Kristang in the Portuguese Settlement of Malacca. Jurnal Bahasa Moden 12: 147-156. 
Scully, V. \& Zuzarte, C. 2017. The Eurasian Heritage Dictionary. Kristang - English. English- Kristang, $2^{\text {nd }}$ edition. Singapore: Straits Times Press.

da Silva, P. 1988. Ordinário da Missa em Papiá Kristang. Revista de Cultura 5: 105-110.

da Silva Rêgo, A. 1942a. Apontamentos para o estudo do dialecto português de Malaca. Boletim geral das colónias 18 (203): 9-71.

da Silva Rêgo, A. 1942b. Apontamentos para o estudo do dialecto português de Malaca. Boletim geral das colónias 18 (208): 3-88.

van der Sijs, Nicoline. 2010. Nederlandse woorden wereldwijd. The Hague: Sdu Uitgevers.

Soh,W.-Y. 2015. Managing Heritage Language Relevance and Language Revitalisation: The Case of Malacca Portuguese Creole. PhD dissertation, University of Malaya.

De Witt, Dennis. 2011. Enemies, friends and relations: Portuguese Eurasians during Malacca's Dutch era and beyond. In L. Jarnagin (ed.), Portuguese and Luso-Asian Legacies in Southeast Asia, 1511-2011, vol. 2, Luso-Asian World. Tenacities \& Plasticities, 257-271.

Wong, K. M. 2019. Kodrah Kristang: The initiative to revitalize the Kristang language in Singapore. In M. Pinharanda-Nunes \& H. C. Cardoso (eds.), Documentation and maintenance of contact languages from South Asia to East Asia, 35-121. Honolulu: University of Hawai'i at Mānoa.

Woordenboek der Nederlansche Taal. 2012. http://gtb.inl.nl. 